\title{
Effect of hot air drying on quality characteristics and physicochemical properties of bee pollen
}

\author{
Ayla $\operatorname{ISIK}^{1}$, Murat OZDEMIR ${ }^{1 \star}$, Ibrahim DOYMAZ ${ }^{2}$
}

\begin{abstract}
The aim of this study was to investigate the effect of hot air drying on quality characteristics, physicochemical properties, morphological structure and organoleptic characteristics of bee pollen, and compute the effective moisture diffusivity and activation energy during hot air drying of bee pollen. Bee pollen samples were dried at 40, 45, 50, 55 and $60{ }^{\circ} \mathrm{C}$. Effective moisture diffusivity $\left(D_{\text {eff }}\right)$ values ranged from $1.38 \times 10^{-10}$ to $4.00 \times 10^{-10} \mathrm{~m}^{2} / \mathrm{s}$, and the activation energy $\left(\mathrm{E}_{\mathrm{a}}\right)$ was found to be $42.96 \mathrm{~kJ} / \mathrm{mol}$. Protein, fat, total carbohydrates and vitamin $\mathrm{C}$ of bee pollen were affected by the drying temperature. Dried bee pollen samples had high solubility index, and had lower $L^{*}$ and $b^{*}$ values as compared with those of the fresh bee pollen. Total color difference $(\Delta E)$ was the lowest for the bee pollen dried at $40^{\circ} \mathrm{C}$. Morphological changes on dried bee pollen surfaces increased with increasing the drying temperature. Bee pollen dried at $40{ }^{\circ} \mathrm{C}$ took the highest sensory scores and retained its quality attributes better than the bee pollen samples dried at $45,50,55$ and $60^{\circ} \mathrm{C}$. Hot air drying at $40^{\circ} \mathrm{C}$ is recommended for the drying of bee pollen.
\end{abstract}

Keywords: bee pollen; hot air drying; effective moisture diffusivity; activation energy; quality.

Practical Application: The use of the best drying conditions for the hot air drying of bee pollen will contribute to obtain bee pollen products with high quality characteristics.

\section{Introduction}

Bee pollen is an important apicultural product containing carbohydrates, proteins, lipids, minerals and fibers (Dias et al., 2016). Bee pollen with high moisture content (20-30 $\mathrm{g}$ water $/ 100 \mathrm{~g}$ product in wet basis or 25-42.9 $\mathrm{g}$ water $/ 100 \mathrm{~g}$ dry solid in dry basis) is perishable after a short period of time from the harvest because it is highly susceptible to microbial attacks (De-Melo et al., 2016). Therefore, the moisture content of the bee pollen is regarded to be between 6 and $10 \mathrm{~g}$ water $/ 100 \mathrm{~g}$ product or between 6.4 and $11.1 \mathrm{~g}$ water $/ 100 \mathrm{~g}$ dry solid to obtain a shelf stable product (Bogdanov, 2004; Campos et al., 2008).

Bee pollen is sold as fresh and dried. Fresh bee pollen needs to be refrigerated between $5{ }^{\circ} \mathrm{C}$ and $10{ }^{\circ} \mathrm{C}$ to keep its quality. Drying preserves the bee pollen for longer periods of time at room temperature without refrigeration by preventing rapid fermentation and microbial spoilage, providing ease of marketability for the bee pollen and increasing profit of the beekeepers (Barajas et al., 2012). Sun drying is the most widely used traditional method for the drying of the bee pollen, but it has some disadvantages such as long drying times, high risk of microbial contamination, high susceptibility to insect infestation and contamination with foreign materials, requirement of large area for drying, high man power costs and almost no control of drying conditions. On the other hand, hot air drying has reasonably shorter process time, lower risk of microbial contamination, more effective sanitary conditions and better control of drying conditions than the sun drying. Therefore, hot air drying has been used in many industrial drying applications including dehydration of food and agricultural products.

Knowledge on the drying kinetics of food and agricultural products is essential to investigate the drying behavior and understand the drying mechanism for a special product better, design a new drying system or improve the existing one, optimize the drying conditions and control the drying operation. The information on hot air drying characteristics of bee pollen is scarce. Midilli et al. (2000) dried bee pollen at $45^{\circ} \mathrm{C}$ in solar and electric assisted dryers and measured weight changes of the bee pollens during the drying. They were unable to study the drying kinetics of bee pollen because they conducted the drying experiments at only one temperature. Barajas et al. (2012) dried bee pollen at two different temperatures $\left(35^{\circ} \mathrm{C}\right.$ and $\left.45^{\circ} \mathrm{C}\right)$ which were not enough to determine the parameters in drying kinetics such as effective moisture diffusivity $\left(\mathrm{D}_{\text {eff }}\right)$ and activation energy $\left(\mathrm{E}_{\mathrm{a}}\right)$. These studies were not devoted to study the drying kinetics of bee pollen and to determine the best drying condition for the hot air drying of bee pollen. On the other hand, hot air drying may affect organoleptic properties and morphological structure of the dried bee pollens. Determination of the effect of drying temperature and drying time on chemical, physical, morphological 
and organoleptic properties of bee pollen is important to obtain bee pollen products with high quality characteristics. One of the most important novelties that the current research brings is that it aims to examine the morphological changes and organoleptic properties of the dried bee pollens. The main difference of the current study from the existing a few reported studies about the bee pollens is that the current study focuses on investigation of the effect of hot air drying on bee pollen quality, physicochemical properties, morphological changes and sensory characteristics of bee pollen, and compute the effective moisture diffusivity and activation energy during hot air drying of bee pollen.

\section{Materials and methods}

\subsection{Materials}

Fresh bee pollen used in this study was obtained from a beekeeper in Erzincan (Turkey) located 39.74 latitude and 39.49 longitude and situated at $1195 \mathrm{~m}$ above sea level. Fresh bee pollens were transferred to the laboratory under chilled conditions within the same day it was harvested and kept in a refrigerator $\left(+4^{\circ} \mathrm{C}\right)$ prior to the drying experiments.

\subsection{Drying experiments}

Hot air drying trials were carried out at five different temperatures $\left(40^{\circ} \mathrm{C}, 45^{\circ} \mathrm{C}, 50^{\circ} \mathrm{C}, 55^{\circ} \mathrm{C}\right.$ and $\left.60^{\circ} \mathrm{C}\right)$ at a constant air velocity of $2 \mathrm{~m} / \mathrm{s}$ in a cabinet dryer (APV \& Pasilac Ltd., Carlisle, Cumbria, UK) as previously described by Doymaz (2004). Drying air temperatures were measured with a digital temperature controller unit integrated with the cabinet dryer operating with an accuracy of $\pm 0.5^{\circ} \mathrm{C}$. Air velocity was measured with an anemometer (AM-4201, Lutron, Taipei, Taiwan) with a sensitivity of $\pm 0.1 \mathrm{~m} / \mathrm{s}$. Prior to the drying trials, the convective hot air dryer had been operated empty for $30 \mathrm{~min}$ so that a steady-state condition would have been attained within the dryer. The bee pollen samples $(25 \mathrm{~g} \pm 0.5 \mathrm{~g})$ were placed uniformly in stainless steel drying trays in a single layer, having a thickness of about $0.004 \mathrm{~m}$. The trays were taken out at $10 \pm 0.1 \mathrm{~min}$ intervals, and the moisture loss of the samples was determined using a digital balance (Ohaus Scout ${ }^{\circledR}$ Pro, Ohaus Corp., NJ, USA) with an accuracy of $\pm 0.01 \mathrm{~g}$. All the trials were conducted in triplicate until the final moisture content of bee pollens reached to $0.088 \pm 0.002 \mathrm{~g}$ water $/ \mathrm{g}$ dry solid. The dried products were packed under vacuum with an aluminum layer containing composite film barrier to oxygen and water vapor.

\subsection{Determination of effective moisture diffusivity}

The moisture contents of the bee pollen at any given time during hot air drying were computed according to the Equation 1 :

$$
M_{t}=\frac{W_{t}-W_{s}}{W_{s}}
$$

where $\mathrm{M}_{\mathrm{t}}$ is the moisture content at any given time ( $\mathrm{g}$ water/g dry solid), $\mathrm{W}_{\mathrm{t}}$ is the weight of sample at any time $(\mathrm{g})$ and $\mathrm{W}_{\mathrm{s}}$ is the weight of dry solid content of sample (g).

Moisture ratio (MR) was calculated from Equation 2 given below:
$M R=\frac{M_{t}-M_{e}}{M_{0}-M_{e}}$

where $M_{o}$ is the initial moisture content (g water/g dry solid), $M_{t}$ is the moisture content at any given time ( $g$ water/g dry solid) and $M_{e}$ is the equilibrium moisture content ( $g$ water/g dry solid). $M_{e}$ is significantly much lower than $M_{t}$ and $M_{o}$ for long drying times so it can be negligible (Baomeng et al., 2014; Ojha et al., 2017).

The drying rate (DR) was calculated using Equation 3:

$D R=\frac{M_{t}-M_{t+\Delta t}}{\Delta t}$

where $M_{t+\Delta t}$ is moisture content at $t+\Delta t$ (g water/g dry solid) and $\mathrm{t}$ is time ( $\mathrm{min})$.

Fick's second law of diffusion equation (Equation 4) was used to calculate effective moisture diffusivity $\left(\mathrm{D}_{\text {eff }}\right)$ values because drying took place in the falling rate period:

$\frac{\partial M}{\partial t}=\left(D_{e f f}\right) \frac{\partial^{2} M}{\partial x^{2}}$

where $\mathrm{M}$ is the moisture content ( $\mathrm{g}$ water/g dry solid), $\mathrm{t}$ is the time (s), $\mathrm{x}$ is the distance in the solid $(\mathrm{m})$, and $\mathrm{D}_{\text {eff }}$ is the effective moisture diffusivity $\left(\mathrm{m}^{2} / \mathrm{s}\right)$.

The solution of Equation 4 for an infinite slab is given in Equation 5 by Crank (1975) assuming that (i) initial moisture is uniformly distributed throughout the sample; (ii) moisture migration occurs by diffusion only in one dimension; (iii) external resistance and shrinkage are negligible; and (iv) temperature and diffusivity are constant:

$M R=\frac{8}{\pi^{2}} \sum_{n=0}^{\infty} \frac{1}{(2 n+1)^{2}} \exp \left(-\frac{(2 n+1)^{2} \pi^{2} D_{e f f} t}{4 L^{2}}\right)$

where $\mathrm{L}$ is the half thickness of slab $(\mathrm{m})$, and $\mathrm{n}$ is the positive integer.

For longer drying periods, Equation 6 can be formed by taking the first term of series solution, and the other terms can be dropped out (Tutuncu \& Labuza, 1996; Doymaz, 2015):

$M R=\frac{8}{\pi^{2}} \exp \left(-\frac{\pi^{2} D_{e f f} t}{4 L^{2}}\right)$

Equation 6 can be linearized by taking the natural logarithm of both sides, and it turns into Equation 7:

$\ln M R=\ln \frac{8}{\pi^{2}}-\frac{\pi^{2} D_{e f f} t}{4 L^{2}}$

From Equation 7, a plot of $\ln \mathrm{MR}$ versus time gives a straight line with a slope as given in Equation 8 from which $\mathrm{D}_{\text {eff }}$ can be determined.

Slope $=\frac{\pi^{2} D_{e f f}}{4 L^{2}}$ 


\subsection{Computation of activation energy}

Arrhenius type equation was used to illustrate the relationship between the effective diffusivity and temperature for the calculation of the activation energy. The activation energy is calculated using Equation 9:

$D_{\text {eff }}=D_{0} \exp \left(-\frac{E_{a}}{R(T+273.15)}\right)$

where $D_{0}$ is a constant or pre-exponential factor $\left(\mathrm{m}^{2} / \mathrm{s}\right), \mathrm{E}_{\mathrm{a}}$ is the activation energy $(\mathrm{kJ} / \mathrm{mol}), \mathrm{R}$ is the universal gas constant $(8.3143 \mathrm{~J} / \mathrm{mol} \mathrm{K})$ and $\mathrm{T}$ is the drying air temperature $\left({ }^{\circ} \mathrm{C}\right)$.

The natural logarithm of the linear form of Equation 9 is given in Equation 10:

$\ln \left(D_{\text {eff }}\right)=\ln \left(D_{0}\right)-\frac{E_{a}}{R(T+273.15)}$

The slope $\left(-E_{a} / R\right)$ of the graph of $\ln \left(D_{\text {eff }}\right)$ versus $1 /(T+273.15)$ is used to calculate $\mathrm{E}_{\mathrm{a}}$.

\subsection{Determination of protein, fat, ash, moisture content and vitamin $C$}

Fresh and dried bee pollen samples were analyzed for crude protein (AOAC method 984.13), fat (AOAC method 920.39), ash (AOAC method 968.08) and moisture content (AOAC method 925.10) (Association of Official Analytical Chemists, 2005). Vitamin C was determined based on AOAC method 967.21 modified by Jiang et al. (2014). Measurements were done in triplicate, and the results were reported in dry basis.

\subsection{Determination of total carbohydrates}

The total carbohydrates are obtained as suggested by Estevinho et al. (2012) from Equation 11:

Total carbohydrates $(g / 100 g)=100-($ ash + proteins + fats $)$

\subsection{Determination of solubility index}

Bee pollen samples ( $5 \mathrm{~g}$ ) were put on a metal strainer and immersed into $100 \mathrm{~mL}$ distilled water at $20{ }^{\circ} \mathrm{C}$ for $10 \mathrm{~s}$. The samples were taken and drained for $5 \mathrm{~min}$ on an inclined perforated surface, gently blotted with a paper towel and weighed. Measurements were done in triplicate. The solubility index is determined from Equation 12 as given by Barajas et al. (2012):

$S I=\frac{W_{d}-W_{r}}{W_{o}-W_{d}} \times 100$

where SI is the solubility index (dried pollen that can dissolve in water) of dried bee pollen, $\mathrm{W}_{\mathrm{r}}$ is the weight of sample after immersion ( $\mathrm{g}), \mathrm{W}_{\mathrm{d}}$ is the weight of sample after drying $(\mathrm{g})$ and $\mathrm{W}_{\mathrm{o}}$ is the weight of sample before drying $(\mathrm{g})$.

\subsection{Color measurements}

The instrumental color parameters of bee pollen samples were determined using a Konica Minolta CR-400 (Konica Minolta, Sensing Inc., Osaka, Japan) chroma meter equipped with a $\mathrm{D}_{65}$ illuminant and operating with CIE $L^{*} a^{*} b^{*}$ ( $L^{*}$ : 0 to $100, a^{*}$ : - green to +red, and $b^{*}$ : -blue to + yellow) color space. Calibration was performed with the white color calibration tile $(\mathrm{Y}=86.6, \mathrm{x}=0.3188, \mathrm{y}=0.3364$ ) prior to the color measurements. Ten separate measurements were randomly taken from the surface of the bee pollen samples inside the quartz cell, and the results were given as the average of ten separate measurements. The color change of bee pollen samples as affected by drying air temperature was characterized by the total color difference $(\Delta E)$ given in Equation 13 (Cao et al., 2016; Rayaguru et al., 2011):

$$
\begin{aligned}
& \Delta E=\sqrt{(\Delta L)^{2}+(\Delta a)^{2}+(\Delta b)^{2}} \\
& \Delta L=L^{*}-L_{0}^{*}, \quad \Delta a=a^{*}-a_{0}^{*}, \text { and } \Delta b=b^{*}-b_{0}^{*}
\end{aligned}
$$

where $L_{0}^{*}, a_{0}^{*}$ and $b_{0}^{*}$ were color parameters of fresh bee pollen, and $L^{*}, a^{*}$ and $b^{*}$ were the color parameters of the dried bee pollen samples.

\subsection{Scanning Electron Microscopy (SEM) analysis}

The structure and morphology of fresh and dried bee pollen samples were analyzed using a scanning electron microscope (Philips XL30 FEG, Oregon, USA) operating at a voltage of $5 \mathrm{kV}$. The bee pollen samples were mounted on SEM stubs, and sputter coated with a thin layer of gold using a sputter coater (Quorum SC7620, Quorum Technologies, East Sussex, UK).

\subsection{Sensory evaluation}

Acceptance tests were carried out with a panel of thirty panelists aged between 20 and 40 years old to measure the degree of liking or disliking by the use of a hedonic rating scale. A verbal hedonic scale of 9 points ( $9=$ liked very much, $5=$ neither like nor dislike, 1 = disliked very much) was used to quantify affective dimension of the consumer perception regarding the dried bee pollen samples (Meilgaard et al., 2016). The panelists evaluated the sensory attributes including visual appearance, color, odor and overall acceptance in individually partitioned booths in an environmentally controlled room $\left(23 \pm 2{ }^{\circ} \mathrm{C}\right.$ and $\left.50 \pm 5 \% \mathrm{RH}\right)$ under white fluorescent light. Approximately $5 \mathrm{~g}$ of samples were placed into odor-free, disposable, white plastic plates which were labeled with five random digits and presented to the panelists in a randomized order (Meilgaard et al., 2016). Each sample was presented to each panelist along with the appropriate questionnaire, one at a time, with a 3 min wait between the samples. Scores higher than 5 were considered as acceptable, indicating that a score below this value for any of the attributes evaluated was deemed that potential consumers have negative perception about the product.

\subsection{Statistical analysis}

At least triplicate measurements were taken to increase precision or decrease uncertainty in the measurements and to better estimate the uncertainty in the measurements by checking how reproducible the measurements are. Results were 
reported as mean \pm standard deviation (uncertainty). One-way analysis of variance (ANOVA) followed by post hoc analysis using Tukey's multiple range test with a significance level (a) of 0.05 was performed to determine statistical differences between the means of the results for the crude proteins, fats, ash, total carbohydrates, vitamin C, solubility index, color and sensory attributes for the bee pollen samples. The differences between the means are regarded as statistically significant if the $\mathrm{p}$-value is less than or equal to 0.05 . All statistical analyses were performed using Minitab 16.1 (Minitab, 2010).

\section{Results and discussion}

\subsection{Drying characteristics}

Bee pollen samples having initial moisture content of $0.28 \pm 0.003 \mathrm{~g}$ water/g dry solid were dried to a final moisture content of $0.088 \pm 0.002 \mathrm{~g}$ water/g dry solid. Drying curves representing the variation of $\mathrm{MR}$ with the drying time at different temperatures are shown in Figure 1. As expected, the MR decreased exponentially with the drying time. Drying air temperature had an important effect on the total drying time. The drying time at $40^{\circ} \mathrm{C}$ was $210 \mathrm{~min}$ while the drying time was reduced to $80 \mathrm{~min}$ when the temperature was increased to $60^{\circ} \mathrm{C}$. The drying time was shortened by $62 \%$ when the temperature was increased from 40 to $60{ }^{\circ} \mathrm{C}$. This is due to the fact that the rate of mass transfer was higher at higher temperatures. Barajas et al. (2012) investigated the effect of temperature on the drying of bee pollens harvested from two zones of Colombia using a tray dryer with hot air at 35 and $45^{\circ} \mathrm{C}$ without air recirculation. For the bee pollens harvested from two different zones of Colombia, drying times at $35^{\circ} \mathrm{C}$ changed between 210 and $297 \mathrm{~min}$ whereas drying times at $45^{\circ} \mathrm{C}$ ranged from 156 to $198 \mathrm{~min}$. In this study, drying time at $45^{\circ} \mathrm{C}$ was $170 \mathrm{~min}$ which is similar to the results reported by Barajas et al. (2012) for the drying of bee pollens at $45^{\circ} \mathrm{C}$.

The drying rate curves of bee pollens are shown in Figure 2. The drying rates were higher at the beginning of the process, and then decreased. Drying rate was predominantly in the falling rate period, indicating that moisture removal in hot air drying of bee pollen samples was mainly governed by diffusion.

\subsection{Effective moisture diffusivity and activation energy}

The $\mathrm{D}_{\text {eff }}$ values at different drying temperatures, calculated from Equation 8, were found to be $1.38 \times 10^{-10}, 1.57 \times 10^{-10}, 1.97 \times 10^{-10}$, $2.24 \times 10^{-10}$ and $4.00 \times 10^{-10} \mathrm{~m}^{2} / \mathrm{s}$ at $40,45,50,55$ and $60^{\circ} \mathrm{C}$, respectively. As the drying temperature was increased from 40 to $60^{\circ} \mathrm{C}$, there was almost 3-fold increase in $\mathrm{D}_{\text {eff }}$. This might be explained by the increased heating energy, which would increase the activity of the water molecules leading to higher moisture diffusivity when the samples were dried at higher temperatures. The $\mathrm{D}_{\text {eff }}$ values were within the range of $10^{-11}$ to $10^{-9} \mathrm{~m}^{2} / \mathrm{s}$ for drying of food materials (Madamba et al., 1996).

The $\mathrm{E}_{\mathrm{a}}$ is the measure of the energy needed to initiate the moisture diffusion from the internal regions of the food material, and it also indicates the sensitivity of $\mathrm{D}_{\text {eff }}$ to drying temperature. The $\mathrm{E}_{\mathrm{a}}$ was calculated by plotting $\ln \left(\mathrm{D}_{\text {eff }}\right)$ versus the reciprocal of the temperature $(1 /(\mathrm{T}+273.15))$ as shown in Figure 3. Results showed a linear relationship due to Arrhenius

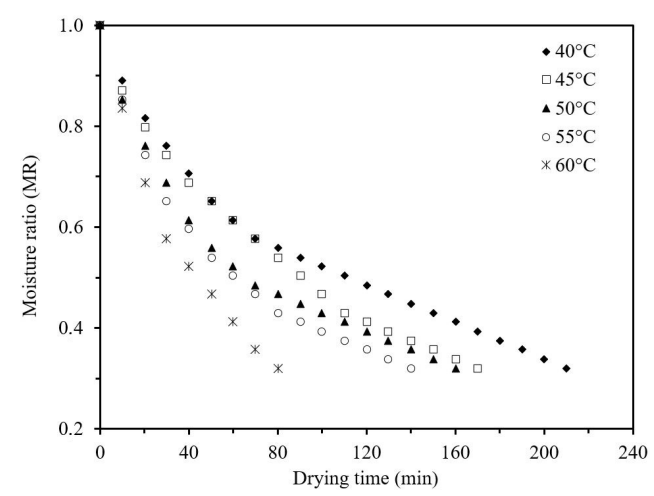

Figure 1. Effect of drying air temperature and drying time on the moisture ratio of bee pollen samples.

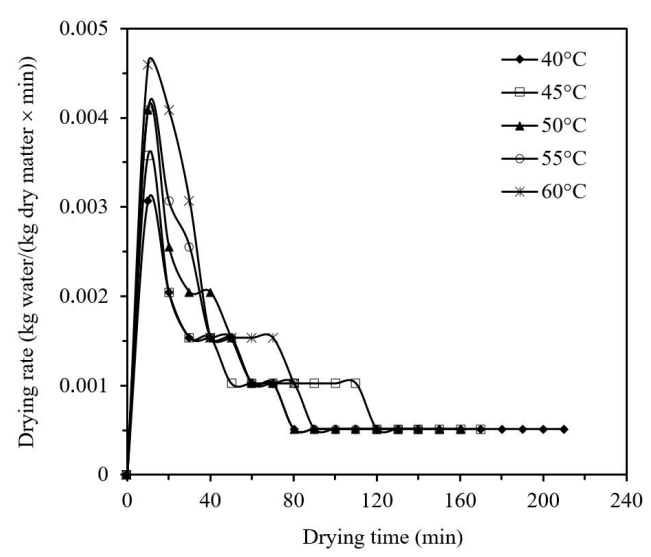

Figure 2. Drying rate as function of drying time at various temperatures.

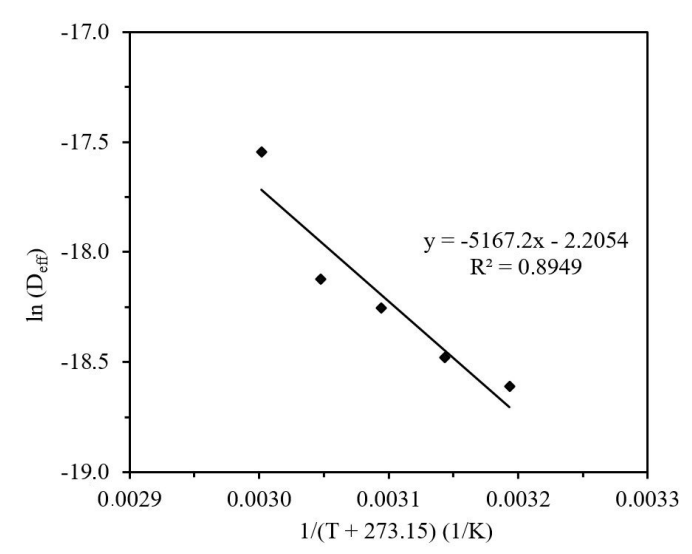

Figure 3. Arrhenius-type relationship between effective moisture diffusivity and reciprocal of absolute temperature.

type dependence. The $\mathrm{E}_{\mathrm{a}}$ was found to be $42.96 \mathrm{~kJ} / \mathrm{mol}$ which lies within the general range of 12.7-110 kJ/mol given for food materials (Aghbashlo et al., 2008). The temperature dependence of the $\mathrm{D}_{\text {eff }}$ of the bee pollen during hot air drying was determined and is given in Equation 14:

$$
D_{e f f}=1.10 \times 10^{-1} \exp \left(-\frac{5167.2}{(T+273.15)}\right) \quad\left(R^{2}=0.8949\right)
$$




\subsection{Effect of drying air temperature on physicochemical properties}

The change in the physicochemical properties of bee pollen dried at different air temperatures is given in Table 1 . The crude protein of fresh bee pollen was $30.36 \pm 0.63 \mathrm{~g} / 100 \mathrm{~g}$ while the crude protein content of the dried bee pollen samples varied from $12.43 \pm 0.07$ to $20.42 \pm 0.31 \mathrm{~g} / 100 \mathrm{~g}$. Almeida-Muradian et al. (2005) reported protein content values of $21 \mathrm{~g} / 100 \mathrm{~g}$ for the bee pollen pellets collected in the south region of Brazil, and Salamanca Grosso et al. (2008) found protein content of $17 \mathrm{~g} / 100 \mathrm{~g}$ for the dried pollen from the Boyacá region of Colombia. These protein content values for the dried bee pollens were close to the protein content results of this study. The crude protein content decreased with increasing the drying air temperature. The loss in crude protein may be linked to the denaturation of proteins as the air temperature increases. The crude protein contents of bee pollens dried at $40,45,50,55$ and $60^{\circ} \mathrm{C}$ were significantly different $(\mathrm{p} \leq 0.05)$ from that of the fresh bee pollen. The crude proteins of the bee pollens dried at 50,55 and $60{ }^{\circ} \mathrm{C}$ were not statistically different $(\mathrm{p} \leq 0.05)$.

The fat content of the bee pollens varied from $5.50 \pm 0.04$ to $7.22 \pm 0.02 \mathrm{~g} / 100 \mathrm{~g}$. The fat content of the fresh bee pollen was statistically different $(p \leq 0.05)$ than those of the dried bee pollen samples except the bee pollen sample dried at $40^{\circ} \mathrm{C}$. Fat content values for the dried bee pollens in this study were similar to those reported by Almeida-Muradian et al. (2005) who found a fat content of 5-9 g/100 $\mathrm{g}$ for the dried bee pollen pellets collected in the south region of Brazil.

Ash content is an account of the inorganic matter found in bee pollen. The drying air temperature did not affect the ash content of the bee pollen. This result is consistent with the results of Barajas et al. (2012) who also found that ash content of the bee pollen was not affected by the drying air temperature. The ash contents of hot air dried bee pollen samples found in this study were similar to those reported by Almeida-Muradian et al. (2005), which ranged from 1.6-3.2 g/100 g and Barajas et al. (2012) which ranged from $1.69-3.19 \mathrm{~g} / 100 \mathrm{~g}$.

Carbohydrates constitute the biggest fraction of the total weight of the bee pollen (Villanueva et al., 2002). Statistically significant differences $(\mathrm{p} \leq 0.05)$ were observed between the total carbohydrates of fresh and dried bee pollen samples. Total carbohydrates in dried bee pollens in this study ranged from $71.81 \pm 0.31$ to $78.70 \pm 0.07 \mathrm{~g} / 100 \mathrm{~g}$ while the carbohydrate content in dried Brazilian pollen samples was found to be $52.10 \mathrm{~g} / 100 \mathrm{~g}$ (Carpes et al., 2009) and the carbohydrate content in Portuguese bee pollen samples changed between 60.82 and $70.76 \mathrm{~g} / 100 \mathrm{~g}$ (Estevinho et al., 2012). Our results were superior to the ones reported by Carpes et al. (2009), and
Estevinho et al. (2012) for Brazilian and Portuguese bee pollen samples, respectively.

Vitamin C contents of dried bee pollen samples decreased with increasing the drying air temperature. There is a significant difference $(p \leq 0.05)$ between the vitamin $C$ contents of dried and fresh bee pollens. Among the dried bee pollen samples, the bee pollen dried at $40^{\circ} \mathrm{C}$ retained almost $76 \%$ of its vitamin $\mathrm{C}$ as compared with that of fresh one. As temperature increased from $40{ }^{\circ} \mathrm{C}$ to $60^{\circ} \mathrm{C}$, the loss in vitamin $\mathrm{C}$ content of the bee pollen samples increased from $24 \%$ to $69 \%$ (approximately 2.9 -fold). Vitamin C is a very thermosensitive compound, and an increase in the drying air temperature and the drying time speeds up the oxidation of vitamin C, which results in loss in vitamin C content of the dried bee pollen. Our results for vitamin $C$ were in good agreement with the results reported by Barajas et al. (2012) who found that vitamin C contents of two different dried Colombian bee pollens decreased progressively with increasing the drying air temperature. Campos et al. (2010) reported that after drying of bee pollen between 32 and $42^{\circ} \mathrm{C}$, the vitamin $\mathrm{C}$ contents decreased by an average of $31 \%$ which is comparable with the decrease in the vitamin C content (24\%) of hot air dried bee pollens at $40^{\circ} \mathrm{C}$ in this study.

\subsection{Effect of drying on solubility index}

The solubility index of hot air dried bee pollen samples after $50 \mathrm{~s}$ of dissolution was between 6.9 and 8.8 (Figure 4). These values revealed that the dried pollen had a high solubility index because the bee pollen samples had dissolution times around $50 \mathrm{~s}$. Barajas et al. (2012) reported that after $50 \mathrm{~s}$ of dissolution, the solubility index values of two different Colombian bee pollens dried at $45^{\circ} \mathrm{C}$ were 3.5 and 5.5 which were lower than the solubility

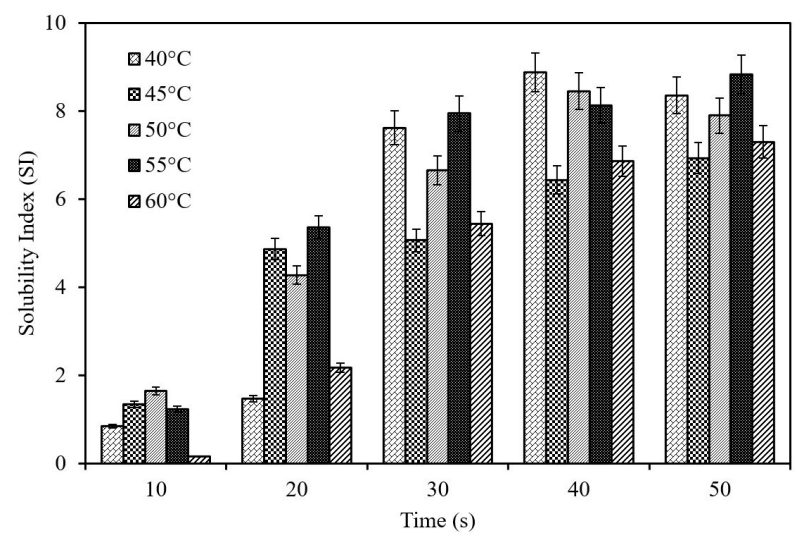

Figure 4. Solubility index of bee pollen dried at various temperatures.

Table 1. Physicochemical properties of fresh and dried bee pollens ${ }^{1}$.

\begin{tabular}{|c|c|c|c|c|c|c|}
\hline & Fresh & $40^{\circ} \mathrm{C}$ & $45^{\circ} \mathrm{C}$ & $50^{\circ} \mathrm{C}$ & $55^{\circ} \mathrm{C}$ & $60^{\circ} \mathrm{C}$ \\
\hline Crude proteins (g/100 g) & $30.36 \pm 0.63^{\mathrm{a}}$ & $20.42 \pm 0.31^{b}$ & $15.56 \pm 0.35^{c}$ & $13.05 \pm 0.11^{\mathrm{d}}$ & $12.43 \pm 0.07^{\mathrm{d}}$ & $13.28 \pm 0.27^{\mathrm{d}}$ \\
\hline Fats $(\mathrm{g} / 100 \mathrm{~g})$ & $5.50 \pm 0.04^{\mathrm{a}}$ & $5.60 \pm 0.01^{\mathrm{a}}$ & $5.86 \pm 0.03^{b}$ & $6.09 \pm 0.05^{c}$ & $7.04 \pm 0.07^{\mathrm{d}}$ & $7.22 \pm 0.02^{\mathrm{e}}$ \\
\hline Ash $(g / 100 \mathrm{~g})$ & $2.18 \pm 0.02^{\mathrm{a}}$ & $2.17 \pm 0.01^{\mathrm{a}}$ & $2.15 \pm 0.01^{\mathrm{a}}$ & $2.16 \pm 0.02^{\mathrm{a}}$ & $2.15 \pm 0.02^{\mathrm{a}}$ & $2.14 \pm 0.01^{\mathrm{a}}$ \\
\hline Total carbohydrates $(\mathrm{g} / 100 \mathrm{~g})$ & $61.96 \pm 0.59^{\mathrm{a}}$ & $71.81 \pm 0.31^{\mathrm{b}}$ & $76.16 \pm 0.34^{\mathrm{c}}$ & $78.70 \pm 0.07^{\mathrm{e}}$ & $78.38 \pm 0.10^{\mathrm{de}}$ & $77.36 \pm 0.29^{\mathrm{cd}}$ \\
\hline Vitamin C (mg/100 g) & $38.48 \pm 0.69^{\mathrm{a}}$ & $29.11 \pm 0.13^{\mathrm{b}}$ & $24.94 \pm 0.07^{c}$ & $16.57 \pm 0.32^{\mathrm{d}}$ & $13.99 \pm 0.12^{\mathrm{e}}$ & $12.11 \pm 0.19^{\mathrm{e}}$ \\
\hline
\end{tabular}

${ }^{1}$ Values are expressed in mean \pm standard deviation, and values with the same letter within the same row are not statistically significant at $\mathrm{p}>0.05$. 
index value of bee pollen dried at $45^{\circ} \mathrm{C}$ in this study. This means that the dried bee pollen samples in this study are more easily soluble in water than the dried Colombian bee pollen samples.

\subsection{Effect of drying on color}

All the dried bee pollen samples showed lower $L^{\star}$ and $b^{*}$ values than the fresh bee pollen while $a^{*}$ values of the dried bee pollen samples were slightly higher than those of the fresh bee pollen, but the difference was not statistically significant $(\mathrm{p}>0.05)$ (Table 2). The parameter $L^{*}$ indicates the darkness or lightness of the color and, in general, the dried bee pollen samples tend to have $L^{\star}$ values higher than 50 . The $L^{\star}$ values of the bee pollen samples dried at 40 and $45^{\circ} \mathrm{C}$ did not differ significantly ( $p>0.05$ ) from the $L^{*}$ value of the fresh bee pollen. Among the dried bee pollen samples, the bee pollen dried at $40^{\circ} \mathrm{C}$ exhibited the highest $L^{*}$ value while the bee pollen dried at $60^{\circ} \mathrm{C}$ showed the lowest $L^{*}$ value. The decrease in $b^{*}$ value is interpreted as a decrease in yellow color. The $b^{*}$ values of the dried bee pollens decreased with increasing the drying temperature. Compared with the $b^{\star}$ value of the fresh bee pollen, there was no statistically significant difference $(\mathrm{p}>0.05)$ between the $b^{*}$ values of the bee pollen samples dried at 40 and $45^{\circ} \mathrm{C}$.

The statistical analysis of $\Delta E$ values of the dried bee pollen samples indicated that $\Delta E$ was the lowest for the bee pollen dried at $40^{\circ} \mathrm{C}$ while the highest $\Delta E$ was attained for the bee pollen dried at $60^{\circ} \mathrm{C}$ in which higher drying temperatures led to larger $\Delta E$ values. As lower $\Delta E$ values are favorable, the color of the bee pollen dried at $40^{\circ} \mathrm{C}$ is the closest to the color of the fresh bee pollen.

\subsection{Scanning electron microscopy}

Fresh bee pollen grains varied in size from 28 to $35 \mu \mathrm{m}$, and were bilaterally symmetrical and mostly had an elliptical shape with a longitudinal crevice (Figure $5 \mathrm{a}$ ). The surface of the fresh bee pollen grains is mostly smooth as compared with those of the dried bee pollens. The morphological changes on the surface of bee pollen grains increased with increasing the drying temperature (Figure $5 b-f$ ). This was due to the fact that more water evaporated as the drying temperature increased, which resulted in increased morphological changes on the surface of the bee pollen grains.

\subsection{Effect of drying on sensory attributes}

Sensory attributes of a food product determine its acceptability by the consumers. Therefore, sensory attributes such as visual appearance, color, odor and overall acceptance of the bee pollen samples dried at different temperatures were scored by the panelists. Mean sensory scores related to sensory attributes are given in Table 3. The visual appearance, color, odor, and overall acceptance scores decreased with increasing the drying temperature. The bee pollen sample dried at $40{ }^{\circ} \mathrm{C}$ took the highest sensory scores from the panelists while the bee pollen dried at $60{ }^{\circ} \mathrm{C}$ took the lowest scores. A significant difference $(\mathrm{p} \leq 0.05)$ was observed between the sensory attributes of bee pollen dried at $40^{\circ} \mathrm{C}$ and those of dried at $60^{\circ} \mathrm{C}$. On the other hand, there was no significant difference $(\mathrm{p}>0.05)$ between the visual appearance, color, odor and overall acceptability scores of bee pollen dried at $40^{\circ} \mathrm{C}$ and those of the fresh bee pollen.
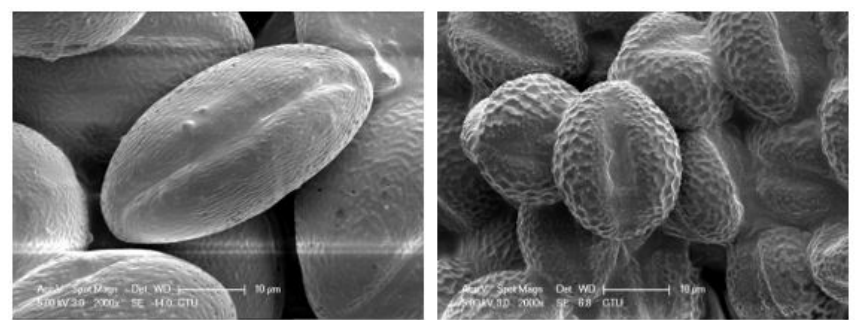

a

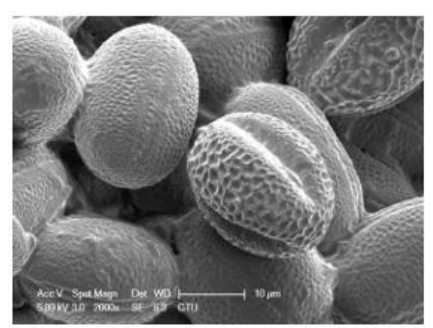

b

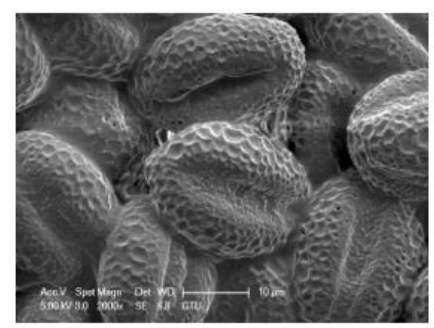

d
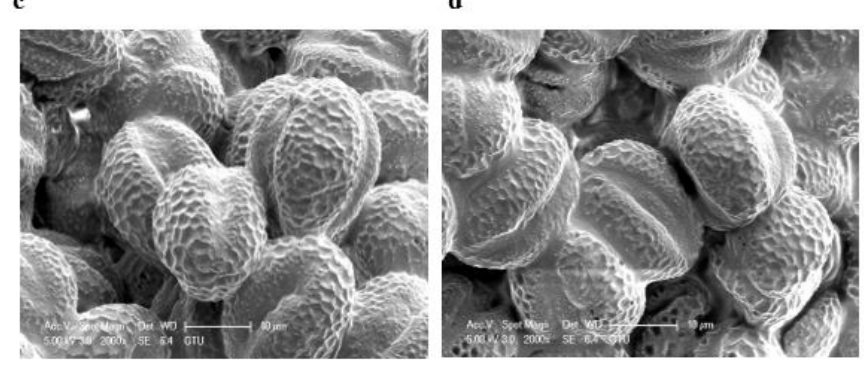

f

Figure 5. Scanning electron micrograph of (a) fresh, and dried bee pollen samples at (b) $40^{\circ} \mathrm{C}$, (c) $45^{\circ} \mathrm{C}$, (d) $50{ }^{\circ} \mathrm{C}$, (e) $55^{\circ} \mathrm{C}$ and (f) $60^{\circ} \mathrm{C}$. Scale bar is $10 \mu \mathrm{m}$. Magnification: $2000 \times$.

Table 2. Color parameters of fresh and dried bee pollen samples ${ }^{1}$.

\begin{tabular}{|c|c|c|c|c|}
\hline Temperature $\left({ }^{\circ} \mathrm{C}\right)$ & $L^{*}$ & $a^{*}$ & $b^{*}$ & $\Delta E$ \\
\hline Fresh bee pollen & $56.50 \pm 0.84^{\mathrm{a}}$ & $10.78 \pm 0.38^{\mathrm{a}}$ & $64.23 \pm 2.22^{\mathrm{a}}$ & - \\
\hline $40^{\circ} \mathrm{C}$ & $55.23 \pm 1.63^{\mathrm{ab}}$ & $10.86 \pm 1.00^{\mathrm{a}}$ & $63.19 \pm 1.84^{\mathrm{ab}}$ & $2.65 \pm 1.42^{\mathrm{a}}$ \\
\hline $45^{\circ} \mathrm{C}$ & $55.00 \pm 1.44^{\mathrm{ab}}$ & $11.32 \pm 0.55^{\mathrm{a}}$ & $61.38 \pm 2.25^{\mathrm{abc}}$ & $3.55 \pm 2.84^{\mathrm{a}}$ \\
\hline $50^{\circ} \mathrm{C}$ & $53.07 \pm 0.79^{b c}$ & $11.33 \pm 0.82^{\mathrm{a}}$ & $59.52 \pm 1.26^{\mathrm{bc}}$ & $5.99 \pm 2.16^{\mathrm{ab}}$ \\
\hline $55^{\circ} \mathrm{C}$ & $52.34 \pm 1.42^{c}$ & $11.52 \pm 0.95^{\mathrm{a}}$ & $59.49 \pm 2.07^{\mathrm{bc}}$ & $6.66 \pm 3.30^{\mathrm{ab}}$ \\
\hline $60^{\circ} \mathrm{C}$ & $50.57 \pm 0.47^{c}$ & $11.82 \pm 1.00^{\mathrm{a}}$ & $57.56 \pm 0.77^{c}$ & $9.19 \pm 2.11^{b}$ \\
\hline
\end{tabular}

${ }^{1}$ Values are expressed in mean \pm standard deviation, and values with the same letter within the same column are not statistically significant at $\mathrm{p}>0.05$. 
Table 3. Sensory attributes of fresh and dried bee pollen samples ${ }^{1}$.

\begin{tabular}{ccccc}
\hline Temperature $\left({ }^{\circ} \mathrm{C}\right)$ & Visual appearance & Color & Odor & Overall acceptance \\
\hline Fresh bee pollen & $8.74 \pm 0.15^{\mathrm{a}}$ & $8.71 \pm 0.18^{\mathrm{a}}$ & $8.77 \pm 0.12^{\mathrm{a}}$ & $8.72 \pm 0.13^{\mathrm{a}}$ \\
$40^{\circ} \mathrm{C}$ & $8.00 \pm 0.39^{\mathrm{ab}}$ & $8.10 \pm 0.37^{\mathrm{ab}}$ & $7.95 \pm 0.27^{\mathrm{ab}}$ & $8.12 \pm 0.28^{\mathrm{ab}}$ \\
$45^{\circ} \mathrm{C}$ & $7.50 \pm 1.10^{\mathrm{bc}}$ & $7.50 \pm 0.71^{\mathrm{bc}}$ & $7.60 \pm 0.62^{\mathrm{b}}$ & $7.58 \pm 0.36^{\mathrm{b}}$ \\
$50^{\circ} \mathrm{C}$ & $6.90 \pm 0.94^{\mathrm{c}}$ & $6.85 \pm 0.63^{\mathrm{c}}$ & $7.10 \pm 1.22^{\mathrm{bc}}$ & $6.83 \pm 0.62^{\mathrm{c}}$ \\
$55^{\circ} \mathrm{C}$ & $5.80 \pm 0.60^{\mathrm{d}}$ & $5.85 \pm 0.55^{\mathrm{d}}$ & $6.50 \pm 0.92^{\mathrm{c}}$ & $6.05 \pm 0.45^{\mathrm{d}}$ \\
$60^{\circ} \mathrm{C}$ & $4.50 \pm 0.50^{\mathrm{e}}$ & $4.60 \pm 1.26^{\mathrm{e}}$ & $4.90 \pm 0.83^{\mathrm{d}}$ & $4.67 \pm 0.66^{\mathrm{e}}$ \\
\hline
\end{tabular}

${ }^{1}$ Values are expressed in mean \pm standard deviation, and values with the same letter within the same column are not statistically significant at $\mathrm{p}>0.05$.

The evaluation of the sensory attributes of the dried bee pollen samples showed that the bee pollen dried at $40{ }^{\circ} \mathrm{C}$ retained its quality attributes better than the bee pollen samples dried at $45,50,55$ and $60^{\circ} \mathrm{C}$.

\section{Conclusions}

Drying air temperature had an important effect on the total drying time. Higher drying temperatures reduced the drying times. The moisture ratio of bee pollens decreased exponentially with the drying time. Drying rate was predominantly in the falling rate period, and it was affected by the drying air temperature. The $\mathrm{D}_{\text {eff }}$ value increased with increasing the drying temperature. The $\mathrm{D}_{\text {eff }}$ values for the bee pollen varied from $1.38 \times 10^{-10}$ to $4.00 \times 10^{-10} \mathrm{~m}^{2} / \mathrm{s}$, and they were within the range of $10^{-11}$ to $10^{-9} \mathrm{~m}^{2} / \mathrm{s}$ given for food materials. The $\mathrm{E}_{\mathrm{a}}$ value was found to be $42.96 \mathrm{~kJ} / \mathrm{mol}$, and it was within the general range of $12.7-110 \mathrm{~kJ} / \mathrm{mol}$ given for food materials. Crude protein, fat, total carbohydrates and vitamin $\mathrm{C}$ of the bee pollen samples were affected by the drying temperature, but the ash content was not affected by the drying temperature. Dried bee pollen samples were found to be highly soluble in aqueous solution. All the dried bee pollen samples showed lower $L^{*}$ and $b^{*}$ values than the fresh bee pollen while $a^{*}$ values of the dried bee pollen were not statistically significant $(\mathrm{p}>0.05)$ as compared with the fresh bee pollen. $\Delta E$ was the lowest for the bee pollen dried at $40^{\circ} \mathrm{C}$. Morphological changes occurred on the surface of the dried bee pollens as the drying temperature increased. The bee pollen sample dried at $40^{\circ} \mathrm{C}$ took the highest sensory scores from the panelists among the dried bee pollen samples. Overall analyses of the drying behavior and evaluation of the sensory attributes of the dried bee pollen samples showed that the bee pollen dried at $40^{\circ} \mathrm{C}$ retained its quality attributes much better than the bee pollen samples dried at $45,50,55$ and $60^{\circ} \mathrm{C}$. Therefore, hot air drying at $40{ }^{\circ} \mathrm{C}$ is recommended for the drying of bee pollens.

\section{Acknowledgements}

The authors would like to thank Gebze Technical University and Yildiz Technical University for providing laboratory equipment in this research.

\section{References}

Aghbashlo, M., Kianmehr, M. H., \& Samimi-Akhijahani, H. (2008). Influence of drying conditions on the effective moisture diffusivity, energy of activation and energy consumption during the thin- layer drying of berberis fruit (Berberidaceae). Energy Conversion and Management, 49(10), 2865-2871. http://dx.doi.org/10.1016/j. enconman.2008.03.009.

Almeida-Muradian, L. B., Pamplona, L. C., Coimbra, S., \& Barth, O. M. (2005). Chemical composition and botanical evaluation of dried bee pollen pellets. Journal of Food Composition and Analysis, 18(1), 105-111. http://dx.doi.org/10.1016/j.jfca.2003.10.008.

Association of Official Analytical Chemists - AOAC. (2005). Official methods of analysis of AOAC international (18th ed.). Gaithersburg: AOAC.

Baomeng, Z., Xuesen, W., \& Guodong, W. (2014). Effect of pretreatments on drying characteristics of Chinese jujube (Zizyphus jujuba Miller). International Journal of Agricultural and Biological Engineering, 7(1), 94-101.

Barajas, J., Cortes-Rodriguez, M., \& Rodriguez-Sandoval, E. (2012). Effect of temperature on the drying process of bee pollen from two zones of Colombia. Journal of Food Process Engineering, 35(1), 134148. http://dx.doi.org/10.1111/j.1745-4530.2010.00577.x.

Bogdanov, S. (2004). Quality and standards of pollen and beeswax. Apiacta, 38, 334-341.

Campos, M. G. R., Bogdanov, S., Almeida-Muradian, L. B., Szczesna, T., Mancebo, Y., Frigerio, C., \& Ferreira, F. J. (2008). Pollen composition and standardisation of analytical methods. Journal of Apicultural Research, 47(2), 154-161. http://dx.doi.org/10.1080/00218839.2008.11101443.

Campos, M. G. R., Frigerio, C., Lopes, J., \& Bogdanov, S. (2010). What is the future of Bee-Pollen? Journal of ApiProduct and ApiMedical Science, 2(4), 131-144. http://dx.doi.org/10.3896/IBRA.4.02.4.01.

Cao, Z. Z., Zhou, L., Bi, J., Yi, J., Chen, Q., Wu, X., Zheng, J., \& Li, S. (2016). Effect of different drying technologies on drying characteristics and quality of red pepper (Capsicum frutescens L.): a comparative study. Journal of the Science of Food and Agriculture, 96(10), 35963603. http://dx.doi.org/10.1002/jsfa.7549. PMid:26612038.

Carpes, S. T., Cabral, I. S. R., Rosalen, P. I., Alencar, S. M., \& Masson, M. L. (2009). Caracterização do potencial antimicrobiano dos extratos de pólen apícola da região Sul do Brasil. Alimentos e Nutrição, 20(2), 271-277.

Crank, J. (1975). The mathematics of diffusion (2nd ed.). Gloucestershire: Clarendon Press.

De-Melo, A. A. M., Estevinho, M. L. M. F., Sattler, J. A. G., Souza, B. R., Freitas, A. S., Barth, O. M., \& Almeida-Muradian, L. B. (2016). Effect of processing conditions on characteristics of dehydrated bee-pollen and correlation between quality parameters. LebensmittelWissenschaft + Technologie, 65, 808-815. http://dx.doi.org/10.1016/j. lwt.2015.09.014.

Dias, L. G., Tolentino, G., Pascoal, A., \& Estevinho, L. M. (2016). Effect of processing conditions on the bioactive compounds and biological properties of bee pollen. Journal of Apicultural Research, 55(5), 357-365. http://dx.doi.org/10.1080/00218839.2016.1248109. 
Doymaz, I. (2004). Effect of pre-treatments using potassium metabisulphide and alkaline ethyl oleate on the drying kinetics of apricots. Biosystems Engineering, 89(3), 281-287. http://dx.doi. org/10.1016/j.biosystemseng.2004.07.009.

Doymaz, I. (2015). Infrared drying kinetics and quality characteristics of carrot slices. Journal of Food Processing and Preservation, 39(6), 2738-2745. http://dx.doi.org/10.1111/jfpp.12524.

Estevinho, L. M., Rodrigues, S., Pereira, S. P., \& Feás, X. (2012). Portuguese bee pollen: palynological study, nutritional and microbiological evaluation. International Journal of Food Science \& Technology, 47(2), 429-435. http://dx.doi.org/10.1111/j.1365-2621.2011.02859.x.

Grosso, G. S., Perez-Figueredo, C. R., \& Vargas, E. F. (2008). Origen botánico propiedades fisicoquímicas microbiológicas del polen colectado en algunas zonas apícolas de la Campiña de Boyacá. In II Congreso Iberoamericano sobre Seguridad Alimentaria, V Congreso Español de Ingeniería de Alimentos y V Congreso Español de Ingeniería de Alimentos (pp. 1-7). Barcelona: CESIA-CIBSA.

Jiang, H., Zhang, M., Mujumdar, A. S., \& Lim, R. X. (2014). Comparison of drying characteristic and uniformity of banana cubes dried by pulse-spouted microwave vacuum drying, freeze drying and microwave freeze drying. Journal of the Science of Food and Agriculture, 94(9), 1827-1834. http://dx.doi.org/10.1002/jsfa.6501. PMid:24526431.

Madamba, P. S., Driscoll, R. H., \& Buckle, K. A. (1996). The thin-layer drying characteristics of garlic slices. Journal of Food Engineering, 29(1), 75-97. http://dx.doi.org/10.1016/0260-8774(95)00062-3.
Meilgaard, M. C., Civille, C. V., \& Carr, B. T. (2016). Sensory evaluation techniques (5th ed.). Boca Raton: CRC Press.

Midilli, A., Olgun, H., Rzayev, P., \& Ayhan, T. (2000). Drying and conservation conditions of pollen. Journal of the Science of Food and Agriculture, 80(13), 1973-1980. http://dx.doi.org/10.1002/10970010(200010)80:13<1973::AID-JSFA719>3.0.CO;2-D.

Minitab. (2010). Minitab. Version 16.1. State College: Minitab Inc.

Ojha, K. S., Kerry, J. P., \& Tiwari, B. K. (2017). Investigating the influence of ultrasound pre-treatment on drying kinetics and moisture migration measurement in Lactobacillus sakei cultured and uncultured beef jerky. Lebensmittel-Wissenschaft + Technologie, 81, 42-49. http:// dx.doi.org/10.1016/j.lwt.2017.03.011.

Rayaguru, K., Routray, W., \& Mohanty, S. N. (2011). Mathematical modeling and quality parameters of air-dried betel leaf (Piper Betle L.). Journal of Food Processing and Preservation, 35(4), 394-401. http://dx.doi.org/10.1111/j.1745-4549.2010.00480.x.

Tutuncu, M. A., \& Labuza, T. P. (1996). Effect of geometry on the effective moisture transfer diffusion coefficient. Journal of Food Engineering, 30(3-4), 433-447. http://dx.doi.org/10.1016/S02608774(96)00028-3.

Villanueva, M. T. O., Marquina, A. D., Serrano, R. B., \& Abellan, G. B. (2002). The importance of bee-collected pollen in the diet: a study of its composition. International Journal of Food Sciences and Nutrition, 53(3), 217-224. http://dx.doi.org/10.1080/09637480220132832. PMid:11951585. 